\title{
Kent Sosyolojisi ve Kentsel Araştırmaların Geleceği Üzerine Bazı Düşünceler
}

\author{
Some Considerations on the Future of Urban Sociology and Urban Research
}

Sevinç GÜÇLÜ*

$\ddot{O}_{z e t:}$ Bu makalede, sosyolojinin bir alt dalı olan kent sosyolojisinin geleceği tartışılmaktadır. Kent sosyolojisi, 1900'lerde gelişmeye başlamış, 1970'lere kadar modernleşme paradigmasının etkisinde kalmış, 2000'lerde küreselleşme ve kent ilişkisi üzerinde durulmaya başlanmıştır. Kent, pek çok disiplinin üzerinde durduğu bir konu olduğu için, disiplinlerarası çalışmaların sayısı gün geçtikçe artmaktadır.

Anahtar Sözcükler: Kent, kent sosyolojisi, küreselleşme

Abstract: In this article, the future of urban sociology and urban research which is sub-lbranch of sociology, is discussed. Urban sociology started to develop in 1900's. Urban sociology has been influenced by the paradigm of modernization in 1970's. 2000 onwards the relation between globalization and the city have begun to be considered. Urban research is in the field of interest of many disciplines and interdisciplinary researches undergoing gradual increase.

Keywords: Globalization, the city, urban sociology

Sosyolojinin en önemli alt dallarından biri olan kent sosyolojisindeki değişimler, bu makalenin konusunu oluşturmaktadır. 1900'lü yılların sonlarından itibaren, 2000'li yıllara kadar kent sosyolojisinde önemli değişmeler meydana gelmiştir. Özellikle makro düzeyde ortaya çıkan eğilimler, küreselleşme, yeni enformasyon teknolojileri, ulus ötesi ve yerel dinamikler, sosyal parçalanmalar, sosyo-kültürel çeşitlilikler, yeni ekonomi politikaları, siyasal ideolojiler, kentleri, kent teorilerini ve kent araştırmalarını etkilemektedir. Bu çalışmada, değişimler saptandıktan sonra kent sosyolojisinin dünyada ve Türkiye'de geleceği üzerinde durulacaktır. Çalışmada, Batı toplumlarının kentleşme süreçleri ve bu süreçlere ilişkin sosyolojik araştırmaları ve kent sosyolojisinin geleceğini konu edinen Amerikan ve İngiliz Sosyoloji Dernekllerinin panellerine ilişkin raporlar üzerinde özellikle durulacaktır. Ayrıca küreselleşme ve kent sosyolojisinin ilişkisi ele alınacaktır.

\section{Kentsel Araştırmaların Dünü ve Bugünü}

Kent insanlık tarihinde ortaya çıkmış önemli olgulardan biridir. Kent konusundan söz etmenin insanlığın bütün gelişimlerinden, başarı ya da başarısızlıklarından söz etmek anlamına geleceğini öne sürmek abartılı olmayacaktır. Giddens'a göre, kent sosyolojisi, diğerleri gibi sosyolojinin yalnızca bir dalı olmaktan fazla bir şeydir; genel sosyolojik ilginin en önemli sorunlarından bazılarının tam kalbinde yer alır (Özyurt, 2007, 111). Toplumsal bilimlerin inceleme nesnesi olarak kenti ele alış biçimine bakıldığında ya da kent toplum bilimi çalışmalarının bir dökümü yapıldığında, birbirinden oldukça farklı alanlara odaklanıldığı görülecektir. Kimi yapıtlar, kentte yaşayan bireylerin davranış kalıplarında kent yaşamına özgü değişimleri incelemiş, kimileri

\footnotetext{
* Prof. Dr., Akdeniz Üniversitesi, Edebiyat Fakültesi, Sosyoloji Bölümü, Antalya, sguclu@akdeniz.edu.tr
} 
toplumsal dönüşümlerin gerçekleştiği kentte ortaya çıkan sınıfsal ayrımlar üzerinde durmuş, kimileri de gündelik yaşam sorunlarına yoğunlaşmıştır. Kent toplum biliminde yapılan çalışmaların birbirlerinden oldukça farklı konulara, farklı açılardan yönelmelerinin ardında kentin çok yönlülüğünün bulunduğu söylenebilir. Tarih, coğrafya, siyaset, ekonomi gibi türlü disiplinlerin çözümlemelerinde kenti dışarıda bırakamamaları da bu duruma bağlanabilir. 20. yüzyılın ilk yarısına değin ortaya konulan yapıtlarda, Wirth'in ve Chicago Okulu'nun etkisiyle, daha çok kentin yabancılaştırıcı etkisinden kaynaklanan konular üzerinde durulmuştur. Sonraki çalışmalarda ise ağır basan yaklaşım, örnek olay incelemesine dayanılarak araştırmaların sürdürülmesi, böylece kentte yaşayan bireylerin güçlü topluluk bağlarına ve toplumsal katılım duygusuna sahip olduklarının ortaya konulması olmuştur. 1970'lerden sonra, kentin, sınıf savaşımının yaşandığı bir yer olarak algılanmasının yansımalarını görmekteyiz. Buna göre kent üzerine evrensel çözümlemeler yapmanın yerine, uluslar arası kapitalizmin yerele, yani kentlere hangi yönde etkilerde bulunduğunu incelemek daha yerinde olacaktır. 1980'li y1llara gelindiğinde, yaşanan toplumsal-ekonomik değişimlerle birlikte kent çalışmaları daha da çeşitlenerek, gençlik, toplumsal cinsiyet, çevre sorunları ve gündelik yaşam odaklı yeni toplumsal hareketler, sermayenin küreselleşmesinin kentlere etkisi (dünya kenti), metropolleşme ve postmodernizm üzerinde yoğunlaşmaya başlamıştır (Duru, \& Alkan, 2002, 7-9).

1960'lı yıllarda kalkınma, modernleşme ekseninde kentsel çalışmaların ele alındığı bir makalede, sözkonusu dönemde, Türkiye'de kentleşme süreçlerine yönelik araştırmacıların temel eğiliminin modernist ölçüler çerçevesinde sürecin olumlanması yönünde olduğu belirtilmektedir. Kentlerin kalkınma ve sanayileşme yolunda merkez kabul edilmesi nedeniyle köylerde yaşayan nüfusun sanayide işgücü olarak yer alması gerekliliği üzerine inşa edilen kurama uygun olarak köylerden kentlere nüfusun akışı modern topluma geçiş aşaması olarak düşünülmektedir. Kurama uygun olmayan görünümler dahi kurama olan güveni azaltmamıştır. Bu görünümleri açılamak için, yine Batı'da geliştirilmiş farklı değişme kuramları ileri sürülmekte ve kurama sığmayan toplumsal olgular "geçici durum" ya da değişmenin sancısız geçişini sağlayan "tampon mekânizmalar" olarak değerlendirilmektedir (Azman, 2009, 124).

Kent sosyolojisi ile ilgili çalışmaların sayıca azalmış gibi görünmesinin en önemli nedenlerinden biri, kent konusunun çeşitli disiplinlerin konusu haline gelmesidir. Kent demografisi ve insan çevre bilimi dışarıda bırakılırsa, kent ve kentsel yaşam araştırmalarına ilginin azalmış olduğu görülüyor. Bu durum kısmen araştırmaların çoğunun genelde kentsel topluluğu, incelenecek özgül bir kurumsal sorunun bir yönü olarak görmelerinden, bağlamın kendisinin araştırma nesnesi yapılmamasından kaynaklanmaktadır. Bu kent ya/da topluluk kuramının gelecekteki gelişimi için gerekli olan karşılaştırmalı kent toplum biliminin henüz var olmadığı anlamına gelmektedir. Bu eksiklik yalnızca Amerikan toplum bilimcilerinin diğer kültürlere ait verileri göz önünde bulundurmamalarından kaynaklanmamaktadır; çünkü çoğunlukla bu verilere araştırmanın demografik ve çevre bilimsel yönü dışında erişmek kolay değildir. Kent araştırmalarının sayısındaki azalışın ikinci bir nedeni, önceleri "kent toplum bilimi" içinde kavramlaştırılan kimi sorunların bir başka kuramsal çerçevede değerlendirilmesinden kaynaklanan, toplum bilimsel bilginin sorun alanı bölümlenmesinde değişim yaşanması olgusudur. Bu durum, günümüzde toplumsal katmanlaşmanın ve kitle iletişiminin, sanayi toplum biliminin sorun alanı içinde kabul edilmesi örneğinde de görülebilir. Kentsel yaşam toplum biliminin kendisini gelecek on yılda (topluluk anlamında) kentsel yapı konusu ile sınırlandıracağı ve alanın bölümlenmesinin süreceğini kabul etmek için kimi nedenlerin var olduğu söylenebilir. Ancak daha uygun bir karşılaştırmalı kent toplum bilimi, bunun ortaya çıkmasını sağlayabilir (Duru, \& Alkan, 2002, 146).

Tatlıdil'e göre, kent sosyolojisindeki eğilimler, sosyologların kullandıkları yöntemlere göre farklılaşmaktadır. Bir sosyolog, özel bir ilgi ve süreklilik içinde, belli bir kavramsal dizge ve yöntemi seçerek, kentte yaşayan sosyal grupları, bunların birbiriyle ilişkilerini, kentsel değerleri, 
kurumları ve çeşitli tipteki örgütleri, kentsel değerlerle ve kentin morfolojik (maddi) yapısıyla bütünleşme sorunlarını, endüstrileşmenin etkilerini, kent toplumunun yerel, ulusal ve uluslar arası ilişkilerini araştırabilir (Tatlıdil, 1992, 25-41).

Kentsel araştırmaların tarihsel olarak izlediği yola bakıldığında, farklı dönemlerde farklı konuların ve açılama biçimlerinin önem kazandığı, ontolojik kabullerin ve bilgiye yaklaşma biçiminin de bu açıklama biçimlerini etkilediği görülmektedir. Özellikle 1980'ler sonrası dönem, küreselleşmenin ve neoliberal ekonomi politikaları uygulamalarının tüm boyutlarıyla dünyadaki üretim ve emek örgütlenmelerine ve düzenleme mekânizmalarına damgasını vurduğu, dünyada coğrafi-mekânsal ölçeklerin ve hiyerarşilerin yeniden yapılandığı yılları içermektedir. $\mathrm{Bu}$ dönemde değişen en önemli kabullerden birisi, yeni iletişim olanaklarılyla sınırların öneminin azalması ile birlikte kentlerin ve bölgelerin diğer alanlarla çok daha yoğun ekonomik ve sosyal ilişkiler içine girmesi ve giderek daha fazla diş dinamiklerin ve uluslar arasi/ulusal güç dengelerinin etkisi altında evrilmesidir. Bu dönemde üretimin coğrafya ölçeğinde ve kentler arası hiyerarşideki dönüşümler, küresel kent/dünya kenti kavramları, yeni üretim süreçleri ve yeni ortaya çıkan yeni sanayi merkezleri, yerel yönetim-demokrasi ilişkileri, kentlerde yeni rant alanları, küresel ekonominin ortaya çıkardığı yeni merkezler, yeni işbölümüne bağlı olarak ortaya çıkan sınıfsal katmanlaşmalar ve bunların mekânsal tercihleri ile şekillenen yeni kentsel ayrışmalar, dolayısıyla kentsel rantın yeniden bölüşümü ile kazanan ve kaybeden grupların incelenmesi yeni araştırma konuları olarak gündeme yerleşmiştir. Değişen araştırma konularının yanı sıra, araştırmaların ontolojik ve epistemolojik kabulleri, diğer bir deyişle gerçekliğin ve bilginin ne olduğuna ve nasıl ulaşılabileceğine ilişkin kavramsallaştırma ve bilim insanlarının bu çerçevede aldığ 1 konum, araştırmalarda kullanılan metodolojiyi ve açıklama biçimlerini etkilemektedir. Özellikle dönüşümün hızlı olduğu zaman/mekân bağlamlarında Eleştirel Gerçekçilik Kuramı uygun bir araştırma çerçevesi ve farklı toplumsal kuramlarla eklemlenebilecek bir meta-kuram niteliği göstermektedir. Pozitivist bakış açısının önerdiği gibi, ortaya çıkmış olgular arasındaki ilişkilerden yola çıkan genellemeler yerine, Eleştirel Gerçekçilik Kuramı ampirik olarak gözlenen dünyanın arkasında keşfedilmesi gereken yapıların ve bunlara içkin güçlerin olduğunu kabul eder (Türkün, \& Kurtuluş, 2005, 9-10).

John Gilderbloom; James L. Spatos ve John J. Macionis'in yazdığ 1 The Sociology of Cities (1987) adlı kitabın eleştirisini “Kent Sosyolojisi Ölüyor mu?” başlığı ile yayınlamıştır. Yazıda, Amerika'da kent sosyolojisinin ölmekte olduğunu belirtmekte, bu yavaş ölümün işaretlerini şöyle belirtmektedir: Son otuz yıldır Amerikan Sosyoloji Derneğinin "community" bölümüne üyelik giderek azalmaktadır. Sosyoloji bölümlerinde Kent Sosyolojisinde doktora tezi oranları azalmaktadır. Sosyoloji dergilerinde kent sosyolojisi ile ilgili makale sayısı azalmaktadır. Çağdaş Sosyoloji'nin yeni editörleri “kent-urban" kategorisini kaldırmışlardır. Yazar bu durumun nedenleri arasında kent sosyolojisinde yeni teorilerin, bakış açılarının geliştirilememesinin olduğunu belirtmektedir (Gilderbloom, 1988, 443-447).

\section{Amerikan ve İngiliz Sosyoloji Derneklerinin Kent Sosyolojisinin Geleceğine İlişkin Düşünceleri}

Beth Perry ve Alan Harding, "Kent Sosyolojisinin Geleceği: Amerikan ve İngiliz Sosyoloji Derneklerinin Birbirine Bağll Oturumlarının Raporu"nu kaleme aldıkları makalelerinde kent sosyolojisinin geleceği ile ilgili önemli konulara değinmektedirler (Perry, \& Harding, 2002, 844-853). Panelistler Martin Albrow (Amerikan Sosyoloji Derneğinin katıldığı panelin başkanı), Alan Harding (İngiliz Sosyoloji Derneğinin katıldığı panelin başkanı), Neil Brenner, Gary Bridge, Patrick Le Gales, Saskia Sassen, Mike Savage ve John Walton'dur. Alan Harding, kent sosyolojisinin giderek artan şekilde parçalandığını, üstünlüğünü kaybettiğini tartışmıştır. Martin Albrow ise çağdaş küreselleşme süreçleri ve kentsel değişme arasındaki ilişkiyi anlamada sosyolojinin rolünü açıklamaya çalışmışır. Panelin yazarlar tarafından değerlendirilmesi şöyledir: Kent 
çalışmaları tarihi boyunca, sosyologların büyük bir öneme sahip oldukları tartışılmıştır. 20. yüzyıl boyunca 1960'ların sonu, 1980'lerin başında kent çalışmalarına sosyologlar egemendi. Önce Chicago Okulu, sonra radikal dönem ve sonra yeni Weberci ve yeni Marksist yaklaşımlar. Bu dönemler boyunca en azından ünlü kent kritikçileri ve reformistleri olan sosyologlar, çağdaş kent toplumlarında yanlış olanı ve sunulan çözümleri analiz etmede kavramsal araçlar kullanmakla ilgilendiler. Bununla birlikte son yıllarda kent çalışmalarında sosyolojinin üstünlügüne meydan okunmaya başlanmıştır. Son 15 yılda diğer sosyal bilimlerden kaynaklanan -politik bilim, coğrafya, ekonomi- bir etkileme söz konusudur. Aynı zamanda, kent sosyolojisinin parçalanması, kentsel yaşam görünümlerinin, yani konut, eğitim, suç, etniklik, kültür vb. ayrı sosyolojilerinin oluşması tartışılmaktadır. Mike Savage, kent sosyolojisinin zayıflı̆̆ını ve güçlü yönlerini tartışmıştır. Global sosyal teori ile çok özel çalışmalar arasındaki ilişkileri ve kent sosyolojisinin global kentler hakkındaki tartışmalar üzerine aşırı yoğunlaşmış olduğunu belirtmektedir. Sosyologların yapısal eşitsizlikler hakkında düşünmeleri, sosyolojik imgelemi kullanmaları, "gündelik-olağan kentsel mekânlar sosyolojisi"ne yoğunlaşmaları gerekmektedir. Aslında, diğer disiplinler, eşitsizliğin çeşitli yönlerini yeterince ele alamamaktadır. Savage, sosyolojinin, kentsel eşitsizlikler konusunu yeni metolarla ele alması gerektiğini belirtmektedir. Kısaca kent sosyolojisinin geleceği hakkında pozitif bakış açısı, geçmiş trendlere ve sağlanmış güçlere dayalıdır, çeşitli kentsel eşitsizlik türlerine duyarlı olan kentsel mekâna geleneksel yaklaşımları yeniden tazeleme ve ortaya koymaya dayalıdır. Kent sosyologları, kentsel çalışmalardaki parçalanma ve disiplinlerarasılığın meydan okumalarına "temellere geri dönerek" cevap verebilirler; yani, sosyolojinin geleneksel olarak en iyi biçimde, yapısal ve sosyal eşitsizlikleri, yoksulluk ve sosyal bölünmeleri ele alarak yapılabileceğini vurgulayarak. Kent sosyolojisinin, eşitsizlik, yoksulluk ve sosyal bölünme üzerinde durarak köklerine dönebileceği evrensel olarak kabul edilmektedir. Aslında hem sosyolojiden hem diğer disiplinlerden panelistlerin çoğunluğu, kentsel çalışmalardaki eklektisizm ve disiplinlerarasıllı̆ı kabul etmektedir. Bristol Üniversitesi'nden Gary Bridge, kent sosyolojisinin eklektik yapısını ve "kimlik kaybl"nı belirtmektedir. Kent sosyolojisinin dışında ve içinde etkili olan üç akımdan söz etmektedir: Mekân, kültür ve doğa. İlk olarak, Bridge, toplum ve mekân arasındaki ilişkilerle kent sosyolojisinin daha fazla ilgilenmesi gerektiğini belirtmektedir. İkinci olarak, kültürel çalışmalardan ortaya çıkan etkilerin bazıları, kent sosyolojisi için de önemlidir. Yapıbozum nosyonu, kent için de artan bir şekilde kabul edilmektedir. Benzer olarak, kentin kamusal alanlarında erkekliğin güçlerinin rolü konusunda veya kolektif hafıza konusunda, kent ve sosyalliği hakkında önemli gelişmeler vardır. Kültürel çalışmaların ikinci etkisi, ekonomi ve kültürü kapsamaktadır. Ekonomik ve kültürel süreçler birbirinden ayrı değildir, birbiriyle iç içedir. Üçüncü akım, doğanın da sosyal olduğu kabulüdür, kentler hem doğal hem sosyal olarak vardır, sosyo-ekolojik süreçlerdir. Kent sosyolojisinin cevap vermesi gereken bir sorusu da, bizim içinde olmak istediğimiz kentlerin sosyo-ekolojik süreç türleriyle ilgilidir. Bir diğer gelecek araştırma alanı, doğanın kentleşmesi ve sosyal ilişkilerle ilişkisidir. Sonuç olarak kent sosyolojisi, esasen kentsel olanı arama şeklindedir; kentin, doğal, sosyal ve kültürel olanla bağlantısını araştırır. Gelecekte, kentsel sosyoloji, kentsel coğrafya, kentsel ekonomi veya kentsel politika olmayacak, daha ziyade kent çalışmaları, kültür ve doğa olarak biçimlenecektir. Yani disiplinlerarasılık ve çok disiplinlilik olacaktır. Kentsel çalışmalardaki disiplinlerarasılık küreselleşme süreçleri ve kent çalışmasında da görülebilir. New York Üniversitesinden Neil Brenner'e göre, kentsel çalışmalar, kent, mekân ilişkisi, küreselleşmenin mekânsallaşması olarak adlandırılır. Kentin mekânsallaşması 1970'lerde kapitalizmin mekânsallaşması ile başlamıştır. (Castells, 1972, Harvey, 1973, Lefebvre, 1991). İlk aşamada tümüyle endüstrileşmiş dünyada kapitalist endüstrileşme süreçleri ile kentsel coğrafyanın ilişkisi, kapital birikimi, işgücünün yeniden üretimi, kapitalist toplumda sosyo-politik çatışma (Castells, 1972), ikinci olarak 1970 ve 1980'lerde kentsel mekân ve coğrafi ölçekte yeniden kavramsallaşması söz konusudur. Ulusal, bölgesel ve global düzeylerde, kapital birikim süreçleri ile kentlerin ilişkisi kurulmaktadır. Brenner'e göre mekânı iki şekilde 
kavramlaştırabiliriz: İlkinde, sosyal bilimler, mekânı statik, sosyal ilişkileri değişmeyen, düzenli bir durum olarak kavramsallaştırır. Burada ulusal ölçekli kentsel sistemler, ulusallaşmış merkezî yer hiyerarşileri söz konusudur. Son yıllarda, kentsel çalışmalara küreselleşme, dünya kenti formasyonu gibi tartışmalar eklenmiştir. İkinci kavramsallaştırmada ise, bölgeselleşmenin bozulduğu, aşırı hareketli sermaye akışının olduğu, global ekonomik süreçlerin söz konusu olduğu, yer, yerleşim ve bölgelerin ortadan kalktığı bir kavramlaştırmadır. Brenner'in de belirttiği gibi globalleşmenin mekânsallaşmasına yeni disiplinlerarası yaklaşımlar gereklidir. Kent sosyolojisi (sosyolojinin bir alt dalı) ve kentsel çalışmalar (tüm disiplinlerin söz konusu olduğu bir çalışma alanı) arasında bir mücadele vardır. Kent sosyolojisi hâlâ önemli sorular ortaya koymaktadır. Patrick Le Gales, sosyologların geleneksel olarak, kentlerin değişen doğası analizlerinde hâlâ yararlı olduklarını söylemektedir. Kent sosyolojisi ve kent içindeki araştırmaların ölüyor ya da ölmüş oldukları düşüncesini reddederek, Le Gales, pek çok toplumun yeni kentleştiğini, "urban" türler arasında farklılaşmaların başladığını tartışmaktadır. Burada kent sosyolojisinin rolü: Farklı kent tipleri arasında ayrımlaştırma yapmak, dünyanın farklı kısımlarındaki kentler arasında ayrımlaştırma yapmak, farklı teorik ve uygulamalı perspektiflerden kente bakmak. Bu anlamda kentlerdeki geleneksel sosyal yapılar, topluluklar, yerel çevreler, politik yapılar ve süreçler, parçalanma, dolaşım, hareketlilik incelenmektedir. Benzer şekilde Chicago Üniversitesinden Saskia Sassen, kent mekânının stratejik önemi ve potansiyelinin yeni ortaya çıkan biçimlerini tartışmaktadır. Kentlerin doğasını ve pozisyonunu bozan durumları tartışmaktadır. İki önemli konuyu ele almaktadır: Birincisi, yerel ve küresel arasındaki farklılık bulanıktır. İkinci olarak kentlerde parçalanma artmaktadır. Panellerden iki eğilim ortaya çıkmıştır. Birincisi kent çalışmalarında disipliner bağların bulanıklaşması, ikincisi alanın parçalanmas1 eğilimi. BSA (İngiliz Sosyoloji Derneği) paneli kent sosyolojisinin bulgularının ve değişmelerinin daha derin bir şekilde incelenmesini sorgulamıştır. ASA (Amerikan Sosyoloji Derneği) paneli kent sosyolojisi çalışmalarında küreselleşmeyi ele almak gerektiğini vurgulamıştır (Perry, \& Harding, 2002, 844-53).

Panel kent sosyolojisinin toplumdaki değişimlere paralel olarak, klasik yaklaşımlar yanı sıra modern yaklaşımları da kullanarak ilerlemesi gerektiğini, disiplinlerarasılığın öneminin ortaya çıktığını, küresel süreçler önem kazanmış olmakla birlikte yerel süreçlerin de ihmal edilmemesi gerektiğini vurgulamaktadır.

Tim May ve Beth Perry, kent sosyolojisinin geleceğini ele aldıkları makalelerinde, Patrick Le Gales, Saskia Sassen ve Mike Savage'nin yanıt ve görüşlerini vererek daha sonra bir değerlendirme yapmaktadır (May, Perry, Le Gales, Sassen, \& Savage, 2005, 343-370). Makalenin önemli noktaları şöyle özetlenebilir: 20. yüzyılda sosyologlar kent ekolojisi üzerinde odaklaşan Chicago Okulundan, yeni Weberci ve yeni Marksist yaklaşımları vurgulayan yeni kent sosyolojisinin radikalizmine kadar, kent çalışmalarına zengin katkılarda bulunmuşlardır. Her iki aşamada da sosyologlar kendilerini kentsel toplumun iç problemlerini ve sosyal konularını çözümleyen ve tanımlayan yenilikçileri ve eleştiricileri olarak konumlandırmışlardır. Kent sosyolojisindeki nosyon krizi 20. yüzyıldaki kentsel konuların doğası ve kente ilişkin çalışmaların disiplinlerarası olmasından kaynaklanmaktadır. Kentsel fenomene ilişkin çalışma artık tek bir disiplinin elinde değildir. Global ve yerel arasındaki ilişkiler, karşılıklı bağlantılılık, ağlar, alt yapılar, akışlar ile uluslararasında karşılıklı bağımlılı̆̆ın ortaya çıkması söz konusudur. Son 20 yılda sosyologlar, diğer sosyal bilim disiplinleri -politik bilim, coğrafya, planlama, ekonomi- gibi, kent çalışmalarındaki merkezi önemlerini kaybettiklerini gördüler. Kent sosyologları, karmaşık kentsel konuları disiplinlerarası bir şekilde ele almaktadırlar. Aynı zamanda sosyal yerinden olma, parçalanma, çatışma ve gerilim, kültürel çeşitlilik, sembolik ekonomi ve rekabet, bağlanma gibi konulara ilgi duymayı sürdürmüşlerdir. Globalleşme çalışmaları, kent sosyologları için, bölge, ölçek ve mekân konularında eşsiz örnekler sağlamıştır. Bu yoğun global ekonomik ilişkiler kapsamında, karşılıklı bağımlılığı oluşturan süreçlerin önemine dayalı bir 
vurgu yoluyla kazanılmıştır. Bu anlamda disiplinlerarasılık, kent sosyolojisi içinde ufukların genişlemesine yol açmıştır. Disiplinlerarasılık kent sosyolojisi içinde bir krize yol açmaz, yeni sorulara yol açar, kentlerin, ekonomik kalkınma sürecinde artan önemini de gösterir. Disiplin, kent içinde örneğin, konut, eğitim, politika ve kültürel çalışmalar, gender (toplumsal cinsiyet) ve cinsellik, suç ve etniklik gibi alanlarda ele alınabilir. Sosyal teori, global kentler hakkındaki tartışmalara yönelmiştir. Kent sosyolojisinin yakın tarihinde iki paradoksal ve paralel gelişme vardır: 1) Çoğu kez büyük boy (makro) teorik çerçevelerle birleşmiş disiplinlerarasılığın gelişmesi, 2) Kent yaşamının daha gündelik, olağan (mikro) unsurlarına ilişkin anlatıya dayalı çalışmaların artışı. Bu tür eğilimlerin açıklanması arayışı, bilim ile toplum arasında hızla gelişen ilişkilerin gözden geçirilmesine yol açar. Yeni bilgi ekonomisi, sosyal bilimlerdeki bilgi üretimini de etkilemiştir. Bio-bilim, genetik, nano-teknoloji, bilim kentleri, bilgi sermayesi, silikon vadisi gibi global pozisyonlara getirmiştir. Bunlar, kentsel çalışmalar sosyolojisinin konumunda, global ve yerel, temel ve uygulamalı araştırma arasındaki ilişkileri daha açık hale getirmeyi gerektirir. Eğer üniversiteler, bilgi ekonomisinin kalbinde ise (Castells, \& Hall, 1994, May, \& Perry, 2003) ve bilgi ekonomisi kentsel ise, kent sosyologları, bölgesel projelerin eleştiricileri olmaktan ziyade politik aktörler olarak görüneceklerdir.

Patrick Le Gales'e göre, kent sosyolojisinin kentsel çalışmalardaki rolünü kaybettiğine ilişkin yaygın bir kabul vardır. Bu nedenle kent sosyolojisinin geleceğine ilişkin soruları ortaya koymak gerekir. Kentsel araştırmanın dinamik alanı, şimdi daha disiplinlerarası olduğunu göstermektedir. Kent sosyolojisinin geleceği sorusu, 20. yüzyıl sonunda, Alman sosyologları Weber, Sombart, Simmel'in, kentler arasındaki kültür, sanat, teknolojik gelişme, kontrol ve üstünlük ilişkilerini ele aldıkları tartışmaları akla getirmiştir. Onlar, belli bir sosyal, ekonomik, politik ve kültürel koşullar dizisinin etkisini tartışmışlardır, yerleşik kapitalizmin devlet, bireysel ve kolektif düşünme biçimleri, yaşam biçimleri, kültürel yaratım ve hayal gücü ile ilişkisini ele almışlardır. Ortaçağ Avrupa kentinin metropolisten farklı olduğunu ele almışlardır. Benzer tartışmalar, kapitalizmin yeni aşamasında, çevresel kriz, ulus devletin erozyonu, artan bireycilik, küreselleşme süreci içinde karşıt eğilimlerin etkileri içinde de yer almaktadır. Gales'e göre büyük boy (makro) teorik çalışma ile mikro uygulamalı çalışmalar arasında bir gerilim vardır. Kentsel alanlar genişlemekte, daha uluslar arası hale gelmekte, iş bölümü değişmekte, sosyolojik teori ile uygulamalı çalışmalar arasındaki boşluk genişlemektedir. Kent sosyolojisinin akademik içeriği konusunda Batılı akademisyenler (ya Amerikalı, ya Batı Avrupalı) üstündür. Giderek Güney Amerika ya da Doğu Avrupa'dan, aynı zamanda Hindistan, Afrika, Çin'den de büyük bir ilgi vardır. Farklı, melez ya da karşıt küreselleşme biçimlerine doğru yavaş eğilim, kent sosyolojisindeki bilgi üretimi üzerinde başlıca etkiye sahiptir. Kent sosyolojisindeki kriz kavramı, daha çok Fransa ve İngiltere'de, neo-Marksist kent sosyolojisinin çöküşüyle ilgili olmuştur. Kent sosyolojisinin geleceği, karşılaştırmalı çalışmanın gelişmesi, entelektüel geleneklerin melezleşmesi, dünyanın farklı bölgelerindeki araştırmaların gelişmesiyle ilgilidir. 1970'lerin yeni kent sosyolojisi devrimi, dünyanın farklı bölgelerinde gelişmiştir, Japonya'dan Brezilya'ya kadar kent sosyolojisinde uluslararası ağların dinamikleri araştırılmıştır. Rüya-hayal (Fantasy) kentler, ulus ötesi göçler, yoksulluk, küresel kentler ve yerel ekonomilerle ilişkisi ele alınmış ve tartışılmıştır. Kent sosyologları, dünyanın farklı bölgelerinden elde ettikleri bilgilerle, farklı paradigmaları tartışmışlardır. Manila, Jakarta, Tahran, Nairobi, Seul gibi başlıca kentler üzerine yapılmış sınırlı miktarda kent sosyolojisi araştırması vardır. Bu tür bir perspektifte, ulusaşırı göçler hakkında yeni sorular, sosyal ve politik düzen, gıda ayaklanmaları, sosyal hareketlilik, ayrım (segregasyon), eşitsizlikler hakkında klasik sorular, hem de küresel-yerel problem alanı, kent sosyolojisinin gelişmesinde önemli olmuştur. Bu eğilimin öncüleri arasında kent sosyologları vardır, onlar ulusal sınırların ötesini ve ulus devletin ötesini daha kolay düşünürler. Kentsel ekoloji modelleri ile Marksist ve neo-Marksist gelenek, küresel kentler, metropolis ve küresel akışlar hakkındaki araştırmada önemli bir güce sahiptir. Kent sosyolojisi, tüm kentlerin aynı 
modelde geliştiği varsayımını kabul etmez. Kent sosyolojisi, kentsel çalışmalarla yoğun diyalogdan yararlanır. Sosyologların ötesinde bu araştırma alanında, antropoloji, coğrafya, kültürel çalışma, kalkınma, planlama, bölge ve kent ekonomileri, çevre çalışmaları, politik bilim ve sosyal tarih vardır. Aslında, kentleşmenin ilk günlerinden itibaren, kentler/metropollere ilişkin muhtelif kavramlar üretilmiş ve karşılaştırılmıştır:

Maddi kent: Fiziki altyapı, binalar, yollar, evler, aydınlatma, kamu binaları, atıklar, meydanlar, surlar, duvarlardan oluşur.

Kültürel kent: Din, inançlar, sanatlar, semboller, düşünceler, temsiller, farkl1lıklar, hayal gücü, duygulardan oluşur.

Politika ve kent politikaları: Güç, üstünlük, hükümet, hareketlilik, kamu politikaları, refah, eğitim.

Sosyal kent: Gündelik yaşam, sosyal hareketler, ayrım (segregation), ekonomik, etnik, toplumsal cinsiyet eşitsizlikleri, ayaklanmalar

Kentin ekonomisi: İş bölümü, üretim, tüketim, ticaret.

Bu klasik sosyal bilim kategorileri, 19. yüzyılın sonunda Marx, Tocqueville, Durkheim, Simmel ve Weber tarafından ortaya konan kavram ve disiplinlerarasındaki iş bölümünden ortaya çıkmıştır. Çeşitli disiplinler arasındaki iş bölümü bilgi üretiminde önemli bir konudur. Kuşkusuz, emperyalist düşünen sosyologlar, diğer disiplinlerin tüm kısımlara yakından bağlanması ya da birleşmesini kent sosyolojisinin bir zaferi olarak düşünebilirler. (Örneğin sosyal coğrafya) Kent çalışmalarında ortaya çıkan eklektisizm, çeşitli kentsel alt disiplinler, önemli sosyolojik sorulara katkıda bulunmada bir firsat olabilir. Anglo-Saxon sosyal coğrafyacılar, risk, şiddet, suç, enerji ve doğanın sosyal boyutu, kentlerde gıdanın rolü gibi konulara 1şık tutmuşlardir.

Gales, küreselleşme sürecinde kentlerin öneminin azalmadığını, tam tersine arttığını belirtmektedir. Ona göre, sosyal yaşamın pek çok alanında sosyolojik çalışmalar, artan bir şekilde sosyalin oluşturucu boyutu olarak ele alınmaktadır. Sosyoloji üzerinde kent sosyolojisinin güçlü etkileri vardır. Örneğin din sosyolojisi ile kent sosyolojisi birbirleri ile ilişkilidir, din sosyolojisinde, kaderciliğin yerini yeniden keşfetme ve hareketlilik, kentlere belirli bir rol vermektedir. Sosyologlar, ulus devlet içindeki kategorilerini kendine özgü olarak değerlendirmektedir. Ulus devletin erozyonu ve küreselleşme karşıtı eğilimler, kentsel mekâna ilginç roller verir. Bir sosyolog olarak, bireylerin ve grupların bir toplumun parçası haline nasıl geldiği sorusu hem ayrım (segregation) ve eşitsizlikler bakımından hem de bütünleşmenin içselleşmesi bakımından önemli bir sorundur. Aslında pek çok sosyolog, toplumlarda ulusallaşmanın bozulması, gelenekselleşmenin bozulmasının etkilerini vurgulamışlardır -artan ölçüde farklılaşmış ulus aşırı kolektif aktörlerin oluşumu ve sosyal düzene katılım ve katkı düzeylerini belirleyerek-. Bir analiz birimi olarak kent, şöyle bir bakış açısı içindedir: Parçalanma, farklılık, yabancılık, mozaik, olasılığa bağlı etkileşimler, hareket eden sınırlar, olaylar ve oluşumlar, akışkan durumlar, kimlik oluşturma süreçleri, etkileşim ve karmaşıklık. Antropologlar, çoklu kimlikleri, kentsel mozaik ve deneyim çeşitliliğini ön plana çıkarırken, bütünleşme, üstünlük, asimilasyon, sosyal düzen, kontrol, eşitsizlik, kapitalist kalkınma modelleri, yapılar, sistemler üzerine dayalı perspektifler geliştirmektedir. Bu konular, kentsel ortamları anlamak için anahtardır.

Saskia Sassen'e göre, kentler hakkındaki araştırmalar, sadece kentsel durum hakkında değil, toplumlarımızın sosyal, ekonomik ve kültürel durumları hakkında da bilgi üretimine katkıda bulunur. Sosyoloji, endüstri kapitalizminin kentin ortaya çıkışındaki kökenlerini ele alır. Durkheim, Weber, Simmel, Park, Burgess, Wirth bu konuları ele alır. Chicago, endüstriyel kapitalist toplumların dinamiklerini anlamak için bir laboratuvardı. Günümüzde karmaşık, geniş, büyük kentler, politik ekonomik, kültürel ve subjektif yeni işleyiş biçimlerinin olduğu yerlerdir. Günümüzde küreselleşme, yeni enformasyon teknolojileri, ulus ötesi ve yerel dinamikler, istih- 
dam ilişkisindeki kurumsal değişmeler, sosyo-kültürel çeşitlilik tipleri gibi değişmeler, kent ve metropoliten bölgedeki değişme eğilimleridir. 1990'larda akademisyenler, kent, bölge, mekân merceği vasıtasıyla bu eğilimlerin bazılarını kavramsallaştırmaya başladılar. Bu eğilimlerin her biri, tıpkı teori ve araştırma için olduğu gibi, kentler için de kendi sonuçları, içerikleri, özgün şartlarına bağlıdır. Ayrıca kentler, bu eğilimlerin her birinin diğerleriyle etkileştiği yerlerdir. Kompleks kent toplumunu biçimlendiren dinamiklerin ve başlıca dönüşümlerin gözlendiği ve hakkında bilgi üretildiği yerlerdir. Bir çalışma nesnesi olarak kent, ilk akademisyenler tarafindan ve daha geniş perspektiflerden çalışanlar için tartışılabilir bir yapı olarak görülmektedir. Günümüzde kent mekânındaki farklılıklar ve makro sosyal eğilimlerin sonucu olarak geleneksel hiyerarşilerin bozulması problem oluşturmaktadır. Küreselleşme kapsamında, bu süreçlerin çoğu, küresel ölçekte işlemektedir. Kentler, artık, kentsel ötesi dinamiklerin dünyası olarak anlaşılmaktadır. Kent, farklı süreçlerin eklemlendiği kompleks bir yapıdır. Bu kavramsallaştırma tipi, kenti, basit, hiyerarşik, coğrafi ölçeğe yerleştirmez, yerel, ulusal, bölgeselden küresele geçişi ön plana çıkarır. Bazı kentler, ulusal düzeyi aşıp küresel mekânlardan biri olarak ortaya çıkar. Bazı kentler bu kapasiteye sahiptir.

Sassen, bir başka makalesinde kent sosyolojisindeki belirli geleneklere meydan okumaları incelemektedir. Bu meydan okumalar, başlıca makro sosyal eğilimlerin ve onların mekânsal örüntülerinin ara kesitinden ortaya çıkmaktadır. Kent ve metropoliten bölge, bu makro sosyal eğilimlerin somutlaştığı ve bu nedenle çalışmanın objesi olarak oluşturulabilen stratejik yerleşimlerin biri olarak ortaya çıkar. Bu eğilimler arasında küreselleşme, yeni enformasyon teknolojilerinin ortaya çıkışı, ulus ötesi ve yerel ötesi dinamiklerin yoğunlaşması, sosyo-kültürel çeşitlilik tiplerinin varlığının ve sesinin güçlenmesi vardır. Bu eğilimlerin her biri, kentler için kendi belirli sonuç, koşul ve içeriklerine sahiptir. Kentler aynı zamanda bu eğilimlerin etkileştiği, çok karmaşık biçimlerdir. Kentler sosyolojinin kökenlerinde yer alan başlıca makro sosyal dönüşümlerin çalışılması için stratejik merceklerdir (Sassen, 2000,143-159).

Mike Savage'a göre, kent sosyolojisinde bir kriz vardır. Krizin farklı yönleri vardır. Birinci ve ikinci kuşak kentsel araştırma ile üçüncü kuşak farklıdır. İlk kuşak, kentsel olanın mekâna bağlı bir topluluk olduğuna inanıyordu. Le Play'in ünlü deyişiyle mekân, iş, gelenek arasındaki ilişkiler gibi. Yine Lynd'lerin çalışmaları: Middletown $(1929,1937)$, Charles Booth'un (1891) İngiliz yoksulları çalışması ve Seebohm Rowntree'nin (1902) çalışması, bu yaklaşımın unsurlarını içeren klasik topluluk çalışmalarıdır. Bu ilk perspektife, ikinci kuşak, kentsel olanın başarılı bir sosyal düzen biçimi olduğunu vurgulayarak meydan okumuştur. Bu ikinci kuşağın kökenleri, Tönnies'in ünlü toplum-topluluk ayrımına gider. Simmel'in "metropol ve zihinsel yaşam" (1908) ifadesi en etkili ifadelerdendir. Bu kavramlaştırma doğrudan doğruya, Chicago Okulu'nun kentsel evrimci düzenin dinamik doğası hakkındaki görüşü içinde yer alır. Chicago Okulu için, ikincil gruplarla birincil grupların modern kentsel yaşamda nasıl yer değiştirdiği önemlidir. "Kentsel toplum öldü, yaşasın başarll kentsel düzen!" Chicago Okulu kent sosyolojisinde 50 yıl ve daha fazla etkili oldu, 1990'lar ve sonrasinda Marshall Berman'ın (1983) ünlü Katı Olan Her Şey Buharlaşıyor, daha sonra Walter Benjamin'in kentsel düşüncesinde kentsel parçalanmanın nasıl önüne geçileceği tartışılıyor. Bu ikinci kuşakta, kent çalışmalarının merkezinde disiplinlerarası şekillenme vardır -planlama, sosyal politika gibi- Başarılı kentsel düzenin potansiyeli konusundaki vurgu, Chicago Okulu ve İngiliz kentsel çalışmaları geleneğinde önemli olan reformist politikaları açıklar: Young ve Willmott ile Gans'ın çalışmalarında etnik gruplar, göçmenler, topluluk bağları ve dayanışma, kentsel mekâna asimile olmaları konuları ele alınmaktadır. Aynı varsayımlar seti, Bellah ve Putnam'ın sosyal kapital düşüncesiyle sürmüştür. Daha sonra sosyal ağ (network) yaklaşımları geliştirilmiştir. Sosyal bağların yapısı araştırılmıştır. Daha sonra İngiliz araştırmalarında güçlü olarak görülen, kent mekânındaki tarihsel bağları taşıyan eski sakinler ile ilgili araştırmalar yaygınlaşmışırı. Yerliler ile kozmopolitler ya da dinî, manevi değerlere önem verenler (spiralistler) arasındaki ayırım ele alınmıştır. 21. yüz- 
yılda artan sayıda yazar, kimlik, aidiyet, kimliğin diasporik biçimleri, küresel akışlar, hareketler, yeni iletişim biçimleri üzerinde durmuştur. Kent sosyolojisi dışında gelişen düşünce biçimlerini kabul etmek önemlidir. 1970'lerde politik ekonomi ve coğrafya yaklaşımları egemendi. Ardından küreselleşme teorileri yaygınlaşmıştır. Savage'a göre üçüncü kuşak gelişmesinin başındadır. İkinci ile üçüncü kuşaklar arasında diyalog geliştirilmelidir. Bu tür bir diyalog içinde kent sosyologları yorumlayıcılar olarak rollerini daha iyi algılayacaklardır.

\section{Küreselleşme ve Kentler}

Sermayenin yeni uluslararasılaşma sürecinin kentler üzerindeki etkilerinden biri de, bazı kentler desteklenip parlatılır ve belirli bir gelişme temposunu yakalarken, bazılarının iyice gözden düşmesi ve çökme tehlikesiyle karşı karşıya kalmasıdır. Aynı mekânsal bütünlük içinde bir yerin yükselişiyle diğerinin gözden düşmesi ve mekânsal yoksulluk (konutların durumu, kültür etkinlikleri, dinlence yerlerinin yeterliliği ve bakımı, yol, su, kanalizasyon gibi alt yapı hizmetleri bakımlarından) içinde olması durumu, özellikle metropoliten kentlerde yoğun biçimde yaşanmaktadır. Diğer bir deyişle, küresel-yerel ilişkilerinin içeriği nedeniyle, günümüzün mekânsal gelişme eğilimleri, farklı kentler arasında rekabete, kentin iç mekânında ise eskiden beri az çok söz konusu olan ve savunmacı kent planlamasıyla, kollektif tüketimle hafifletilmeye çalışılan ikili yapının daha da keskinleşmesine neden olmaktadır (Doğan, 2001, 97-123).

Son 20 yıllık dönemde dünya ekonomisinde hızlanan uluslararasılaşma eğilimlerinin hem gelişmiş ülkelerle diğer ülkeler arasındaki hem de ülkelerin kendi içindeki gelir dağılımı eşitsizliklerini artırdığ 1 gözlenmektedir. Bugün hem az gelişmiş hem gelişmiş ülkelerde, kentlerde, geniş toplum kesimlerinin giderek yoksullaşması, marjinalleşmesi ve dışlanması söz konusudur. Özellikle ulus-devletin denetim gücünü sınırlayarak, "siyasal bir güç kaynă̆ı oluşturmayan kentler" düzeyinde bir atomize anlatan ve ulus-devletin vesayet denetimini aratacak yeni bağımlılık ilişkilerini doğuran bir yerelleşme sürecini içeren küreselleşme projesi de kent içi ve kentlerarası eşitsizlikleri şiddetlendiren etkilerde bulunmaktadır. Kentin zengin kesimleri küresel ölçekte gerçekleşen mal, hizmet, bilgi ve kültür alışverişinin tüketicileri olarak bu sürece eklemlenirken ezilen sınıflar ise bu sürecin dışladığı kesimler olarak yoksulluğa mahkum edilmektedir. Özetle, kent mekânlarının küresel sermayenin kontrolü altına girmesi ve devletin, eşitsiz mekânsal gelişmelere müdahele olanaklarının sermaye lehine tırpanlanması, kent içinde toplumsal ve mekânsal farklılaşmaların şiddetini artırmaktadır (Kaygalak, 2001, 124-172).

Dünya ölçeğinde hızlanan sermaye akışlarının yönünü ve bileşimini belirleyen kararların, ulus-devletlerin siyasi denetiminden çıkıp bir avuç küresel metropolde nüvelenmesi, son yirmi yılın en çok yazılan konularından birisi oldu. İlk Friedmann'ın “Dünya Kenti Hipotezi” (1986) başlıklı bir makalesinde formüle ettiği biçimiyle, çok uluslu şirketlerin bu metropollerde üslenmesinin nedeni, stratejik önem taşıyan finans sigorta, iletişim gibi işlemlerde ihtisaslaşmış olmaları. Dünya metropollerinin küresel sermayeyi adeta paratoner gibi çekmesi, beraberinde olağanüstü varlık ve zenginlik getiriyor. Ancak aynı anda, bu varlık birikimi vergilendiremeyen, arsa ve emlak fiyatlarındaki spekülatif artışı kontrol edemeyen metropol yönetimleri iflasın eşiğine getiriyor. Friedmann, bu durumda dünya kentlerinin yönetilemez hale geldiğini vurguluyor. Bu kentlerin sorunlarının metropol ölçeğinde çözümlenmesi yerel yönetimlerin siyasi ve ekonomik gücünü çok aşıyor. Ulusal ölçekte ise, neo-liberal politikalar benimseyen devletlerin refah harcamalarında kısıntıya gitmesi, mevcut durumu büsbütün çözümsüzleştiriyor. Friedmann'ın hipotezi, dünya kentlerinin küresel ekonominin en zengin, ama aynı zamanda en sorunlu metropolleri olmaya adeta mahkum olması. Friedmann'dan sonra başta Saskia Sassen olmak üzere, küresel kentlerin çok uluslu şirketlerin karar merkezi olmaktan çok, dünya ekonomisinin işleyişini sağlayan stratejik hizmetlerde ihtisaslaştığını savundu. Küresel metropollerin ana özelliği, başta fon akımlarını sağlayan ve denetleyen finans kurumları olmak üzere, bankalar ve sigorta şirketleri, iletişim telekomünikasyon, bilgisayar ve veri servisleri, global 
piyasalara yönelik medya, pazar araştırması, reklamcılık şirketlerini barındırmaları (ÖncüWeyland, 2005, 15-16).

Özellikle küreselleşme nedeniyle hızla değişmekte olan kentler hakkında bildiğimiz ve düşündügümüz şey aşağıdakileri kapsar:

- 1989'da soğuk savaşın sonu ve sonrasında genel global barış

- Başlıca ticaret engellerinin çöküşü ve global ticaret gibi yeni bölgesel ticaret bloklarının ortaya çıkışı

- Yeni iletişim biçimleri yoluyla bağlanmışlıkta hızlı artış: Fax, internet, fiber-optik kablolar, artan iletişim miktarının dijitalleşmesi ve benzeri (önce elitler arasında daha sonra geniş halk arasında bu aletlere sahipliğin hızla büyüyen bir şekilde artışı)

- Dünyanın pek çok ülkesinde yurttaşların eğitiminin olağanüstü yayılması, böylece daha çok yurttaşa kendini değerlendirme duygusu ve pek çok kamusal konuda düşünceleri biçimlendirme ve okuma yeteneği

- Tarımsal ve endüstriyel çalışmanın azalışı ve basit işlerin insan yerine makine ve bilgisayarlarla yer değiştirdiği daha profesyonel, hizmet yönelimli teknik ağırlıklı işlerin artışı (Clark, 2000, 3-45).

Saskia Sassen, ustalıkla geliştirdiği bireşimli açıklamalarında yerel mekânın yeni küresellik içindeki önemi üzerine temel bir iddia sunar. Sassen, yerin (place) küreselleştirmeyi oluşturan insan ve sermaye dolaşımının merkezinde olduğunu ve küreselleşen bir dünyada kentsel mekânlara odaklanmanın beraberinde ulusal ekonomilerin hızla azalan öneminin farkedilmesini getirdiğini ileri sürer. Öte yandan, aynı zamanda küreselleşmenin belirli yerlerde temellenmiş belirli toplumsal ve ekonomik yapılar yoluyla gerçekleştiğinde israr eder. Bu, üretimden finansa doğru ekonomik değişimle tanımlanan tanıdık bir küreselleşme resmi üzerine oturur. Küresel kentler 1970'lerde, küresel mali sistem önemli ölçüde genişlediğinde ve doğrudan yabancı yatırıma, doğrudan üretici işlevlere yatırılan sermayenin değil sermaye piyasalarına doğru ve bunlar arasında hareket eden sermayenin hükmetmeye başladığı zaman ortaya çıktı. Bu da ardından, finans ekonomisinin komuta ve kontrol merkezlerinde yoğunlaşan yan üretici servislerde önemli bir genişleme üretti ve yeni kentsel biçimler zenginlik ve fakirlik arasındaki aşırı çatallaşma, sınıf ilişkilerinde çarpıcı yeniden örgütlenmeler ve yeni göçmen iş gücü akımlarına bağımlılık ile şekillendi. Bu tabiki, paradigmatik küresel kenttir. 1970'den bu yana, ekonomik güç dengesi "Detroit ve Manchaster gibi üretim mekânlarından, finans ve yüksek derecede özelleşmiş servis merkezlerine kaymıştır" (Sassen, 1992: 3252'den Smith, 2006, 13-29).

Hâkim söyleme göre dünya kenti, küresel ekonominin kontrol, yönetim ve organizasyon merkezi olarak tanımlanmaktadır. Friedmann'a göre uluslararası sermayenin yoğunlaştı̆̆ 1 ve birikiminin gerçekleştiği mekânlardır. Bölgesel, ulusal ve uluslararası ekonomiler bu kentlerde eklemlenirler. Sassen ise dünya kentlerini sadece kontrol ve yönetim merkezleri olarak değil, aynı zamanda ticaret ve hizmet sektörü ile finansal yeniliklerin üretiminin de gerçekleştiği kentler olarak tanımlayarak dünya kenti kavramına yeni bir boyut kazandırır. Uluslararası finansın, uluslararası firmaların genel merkezlerinin buralarda yoğunlaşması, küresel ulaşım ve iletişim ağlarına sahip olma, yüksek düzey uzmanlaşmış hizmetlere sahip olma, medya ve kültür aracılığıyla ideolojik sirayet küresel kentlerin temel özellikleri olarak tanımlanmıştır. Kentin küresel ekonomiye eklemlenme ile birlikte istihdam yapısı, gelir dağılımı ve mekânsal organizasyonunun değiştiği ileri sürülmüştür. Sosyal kutuplaşma ve mekânsal ayrışma küresel kentin temel yapısal özellikleri olarak tanımlanmıştır. Küresel kentlerin dünya ekonomisiyle entegrasyon biçim ve derecelerinin küresel kentler arasında bir küresel kent hiyerarşisi yarattı̆g 1 ileri sürülmüş̧ür (Öktem, 2006, 53-65).

Küreselleşme sürecinde kent sosyolojisinin ilgi alanına giren diğer bir konu soylulaştırma ve bu sürecin toplum katmanlarına etkisidir. Soylulaştırma (gentrification) sosyal ve mekânsal olarak gerilemiş eski/tarihî kent içi alanlarının yeniden yapılanmasıdır. Bu süreç çoğu zaman, yeni 
orta sınıf ve işçi sınıfı olmak üzere iki farklı sınıfın karşılaşması biçiminde başlayıp, işçi sınıfının veya düşük gelirli kesim ile farklı marjinal grupların yerinden edilmesi ile sonuçlanmaktadır. Bu durum mekânsal ve sınıfsal ayrışmayı ve eşitsizliği yaratması ile bölüşüm ilişkileri ile de bağlı hale gelmektedir. Sürecin gelişimi; sınıf ve cinsiyet ayrımları ile mülkiyet, üretim, tüketim ve yaşam biçimleri gibi çok yönlü toplumsal bir süreci içermektedir. Konu, daha çok tüketim ve yaşam biçimlerine bağlı taleplerin değişmesi biçiminde gündeme gelse de arz yönlü etkenler soylulaştırmada belirleyici koşulları oluşturmaktadır. Kent merkezlerinin veya kent içinin eski ekonomik ve sosyal canlılığını kazanması veya yaşadığı bazı sorunları aşması açısından izlenen bir diğer strateji ise kültür temelli bir kent ekonomisi yaratma hedefidir. Bu tür bir kent politikasını kapsamlı bir şekilde çözümleyen Zukin, kentlerdeki bu son dönem değişimi, kentsel yaşam biçimi çerçevesinde inceler. Çalışmalarında, kentlerin "kültürel" niteliğinin bir dönüşüm aracı olarak nasıl kullanıldığını ortaya koyar. Bu yönelim, yeni bir ekonomi politik olarak ele alınmaktadır (Şen, 2006, 65-77).

Küreselleşme sürecinde kent mekânındaki değişmeler ve bu değişmelerin sosyo-kültürel yapıya yansımaları hakkında İstanbul kenti ve sınırlı sayıda İzmir ile ilgili çalışmaların (Yıldırım, \& Haspolat, 2010) dışında kent sosyolojisinde çalışma bulunmamaktadır.

Kente dair bu dönüşümler, kültür endüstrilerinin oluşumuna da eşlik etmektedir. Post modernizmin yükselişi, sanayi sonrası üretim tarzı ve buna bağlı olarak ortaya çıkan kimlik ayrımları, hizmet sektöründeki büyüme, "bebek patlaması" kuşağındaki olgunlaşmanın sonuna gelinmesi ve bu kesimin tüketici olarak yüksek beklentilere sahip olması gibi yapısal bir dizi değişim, kent merkezlerinin ve çevresinde yer alan semtlerin soylulaştırılmasını doğurmaktadır. Seyahat, kültür ve eğlenceye dair yeni tüketim ihtiyaçlarını karşılamak üzere bazı yeni kentsel tüketim mekânları oluşmaktadır. Kültür başkentleri arasındaki rekabet ise daha fazla turist çekmek üzere çeşitli kentsel tüketim biçimlerinin yoğunlaşmasına neden olmaktadır. Giyim, film vb. tüketim ürünleri "estetik" ürünler olarak genelleştirilmektedir. Bunlar uluslararası bir standardı yakalamış olanaklar olarak sunulmaktadır. Restoranlar, cafe-bar ve butik oteller, sanat galerileri gibi yerler, gerek emlak piyasası açısından gerekse reklam, satış ve eğlence sektörleri açısından cazip hale gelmektedir. Kent yönetimleri de bu süreçte "estetikleştirme" girişimlerini destekleme stratejisine yönelmektedirler. Dolayısıyla kamusal mekânlar, her kesimi bir araya getirebilen bir nitelikten uzaklaşarak, özel grupların kontrolüne girmektedirler. Ayrıca bu mekânlarda görsel tüketim öne çıkmaktadır. Ekonomik gelişmenin kültürel stratejileri çeşitli biçimlerde olabilmektedir. Tarihsel korumadan başlayıp yeni müzelerin ve yeni turizm odaklarının oluşturulması gibi stratejiler bunu destekleyen uygulamalardır. Bütün bunlar, gelişmiş sanayi toplumlarındaki "kültürel dönüş"ü ve üretim imajının enflasyonuna karşı olan cevabı da göstermektedir. Bunun yanı sıra yeniden gelişmenin kültürel stratejisi, finansal araçlar, bilgi ve kültür -sanat, yeme-içme, moda, müzik ve turizm- gibi soyut ürün türlerine dayalı bir sembolik ekonominin olgunlaştığı kent merkezlerinin öneminin artmasını da yansıtmaktadır. Bu sembolik ekonomi, kültürel sembollerin üretimi ile de karşıllklı bir ilişkiye dayanır. Bunların içinde üretildiği ve tüketildiği mekânlar da öne çıkar. Bu mekânlar kapsamında ofis, ev, restoran, müze ve hatta sokakları da sayabiliriz Batılı erken kapitalistleşen ülkelerde soylulaştırma süreci 1960'11 yıllarda başlamış ve 1970'li yıllarda hız kazanmıştır. Kentsel mekân, bu yıllarda önemli bir birikim aracı olmaya başlamıştır. Bazı kentsel alanlar yeniden değerlenirken, diğer alanlar ise kentsel gerilemeyi yaşamaya başlamıştır. Türkiye gibi geç kapitalistleşen bir ülkede ise soylulaştırma neoliberal politikaların etkisinde ve özellikle 1990'lı yıllardan itibaren belirgin olarak ortaya çıkmıştır. $\mathrm{Bu}$ son dönem, soylulaştırmanın küresel bir strateji olarak geç kapitalist ülkelerde de yaygınlık kazandığını göstermektedir (Şen, 2006, 65-77).

Soylulaştırma, ilk olarak sanayi sonrası toplumlara özgü bir süreç olarak ortaya çıktıysa da, 1980'lerden itibaren küreselleşmeyle ve çevre ülkelerin kapalı ekonomilerinin küresel ekonomiye eklemlenmesi ile soylulaştırma süreci küresel bir kimlik kazanmıştır denilebilir. Örneğin, 
büyük bloklar halindeki işçi sınıfı konutlarının satıldığı ve "yuppi” piyasası için yeniden geliştirildiği, Londra'nın Battersea bölgesi ve Los Angeles’taki Pacific Rim bölgesi birer soylulaştırma örneği olarak değerlendirilebilir. Ancak, soylulaştırma süreci için genelde verilen tipik örnek, New York'un SoHo semtidir. Bu semt, Bourdieu'nun “yeni kültür aracıları" olarak adlandırdığı, sanatın ve kültürün bir meta olarak pazarlanmasında rol oynayan aktörlerin öncülügünde, bir sanatçılar kolonisi olarak adeta yeniden yaratılmıştır. Bunun yanı sıra, İngiltere'de Birmingham'da, Newcastle'da, İskoçya'da Edinburgh ve Glasgow'da soylulaştırma örneklerine rastlanmaktadır. $\mathrm{Bu}$ liste, çok sayıda sanayileşmiş kenti içerdiği gibi, soylulaştırma süreci Meksika ve Türkiye (İstanbul) gibi gelişmekte olan ülkelerin kentlerinde de gözlemlenmektedir (Uysal, 2006, 77-93).

$\mathrm{Bu}$ süreci toplumumuzda pek çok kentte görebiliyoruz. Kentsel mekândaki değişim ve dönüşümler yerel yönetimlerin de son y1llarda ilgi odağ 1 haline gelmiştir.

1970'lerden sonra da üst-orta sınıfların kent merkezinden kaçı̧̧ları devam etmişti; kent çeperlerinde kurulan, güvenlik ve kentsel donatılar açısından köhnemiş kent merkezine nazaran çekiciliği olan, çok sayıda site yerleşiminin kurulması ve uydu kentlerin inşası günümüzde de sürmektedir. Bununla birlikte, yeni kapitalist üretim ilişkilerinin yarattığı, farklı tüketim alışkanlıklarına sahip, sınıfsal kökenleri aynı olsa da klasik burjuvaziden birçok bakımdan farklılık gösteren yeni bir sosyal sınıfın doğuşu da, bu dönemde gerçekleşmişti. Kimi zaman kentli genç profesyoneller olarak da adlandırılan bu kuşak, savaş sonrası nüfus patlamasının ürünüdür ve kendi yaşam biçimlerini geliştirmişlerdir; geç evlenme, az çocuk sahibi olma anlayışı, alışveriş ve eğlencenin yoğun biçimde yaşanması, kazançları biriktirmek yerine harcamak düşüncesi bu yeni sınıfın "hayat tarzlarının" temelinde yer almaktadır. Sözü edilen hayat tarzları ile yeni burjuvazi (kimi zaman "yuppi"ler ve bunlardan farkl1 olarak "Bobo"lar/Bohem-Burjuvalar kavramları da kullanılmaktadır), ebeveynlerinden farklı tüketim alışkanlıklarına, sosyal ve kültürel gereksinimlere sahiptir. Bu çerçevede, genellikle 1980'ler sonrasında genişleyen, finans, bankacılık sektöründe ya da Mike Featherstone'nun üzerinde durduğu gibi "kültür aracıları" olarak çalışan, veya akademisyenlik, mimarlık, sanatçılık ve benzeri marjinal mesleklere sahip genç profesyonellerin, gereksinimleri farklı olduğu gibi kentsel mekândaki konut tercihleri de farklı olacaktır. Güvenlik, kentsel donatılar, çevre kirliği, trafik gibi kent merkezinin külfetlerinden kaçan seleflerinden farklı olarak, yeni orta sınıfın kültürel ve sosyal gereksinimlerini rahatça karşılayabilecekleri ve tarihî-kültürel dokusuyla ön plana çıkmış kent merkezlerindeki semtlere yerleşmeye ilgi duymaktadırlar. Bir başka deyişle, "eski" burjuvazi hızla kenti terk ederken, "yeni" burjuvazi kentin ve kent merkezinin getirilerini yeniden keşfetme eğilimindedir. İşte bu tersine işler gözüken süreç, bizi soylulaştırma kuramlarının üzerinde durmaya zorlamaktadır. Soylulaştırma (gentrification), bir kavram olarak ilk kez 1964 yılında sosyolog Ruth Glass tarafından, Londra'nın işçi mahallerindeki konutları orta ve üst sınıfın satın alması, bunların yerine şık ve lüks konutlar yapmaları ve bu bölgelerin sosyal karakterini değiştirmeleri ile ilgili olarak kullanılmıştır. Soylulaştırma, en genel tanımıyla gerilemiş olan eski kent içi mekânlardaki yeni bir sınıfsal ve mekânsal ayrışmayı ifade eder; çok yönlü bir dönüşümün sonucu olarak kentsel yeniden yapılanmanın bir parçası ve aynı zamanda da sonucudur. Soylulaştırma, bir kentsel yenilenme ve mekânsal dönüşümden çok daha fazlasına tekabül etmektedir. Bu süreç, kent içi bölgelerin sanayiden ve liman faaliyetlerinden arındırılmasını gerektirmektedir (Uysal, 2006, 77-93).

Tarih boyunca kentlerde kültür, fonksiyon ve statüye bağlı parçaların örneklerini her zaman diliminde yakalamak mümkün. Ancak bugün için yeni olan şey, kent içi mekânsal ayrışmanın nedenleri, ortaya çıkış biçimi, ölçeği ve etkileri üzerine odaklanmaktadır. Coğrafya, kentsel sosyoloji ve planlama disiplinlerini kapsayan geniş bir yazın dilimini incelediğimizde, özellikle 1970'lerden itibaren küresel düzlemdeki gelişmelerin sonucu kentlerde mekânsal ayrışma ve dışlanma eğilimlerinin arttığı yönünde bir görüş birliği olduğunu gözlemliyoruz. Pek çok yazar 
başta küreselleşme olmak üzere, üretim biçimlerindeki farklılaşmaya, refah devleti anlayışındaki zayıflamaya ve teknolojik değişikliklere bağlı olarak toplumsal eşitsizliklerin keskinleştiğine, sosyal kutuplaşmanın arttı̆̆ına ve ayrışan kent parçaları arasındaki çizginin kalınlaşarak daha belirgin bir hale geldiğine dikkat çekiyor. Bu noktada vurgulanan bir diğer konu da kentlerde, her kent için farklılaşmakla birlikte, yeni bir ikiz sürecin yaşanmaya başladığı. Öyle ki kentler bir yandan daha belirgin ve daha fazla mekânsal kompartımanlara ayrılırken, diğer yandan bu parçaların her birinin içinde bir tümleşme süreci yaşanıyor. Barınma, çalışma, rekreasyon ve sosyalleşme alanları kendi kendine yeterli yeni sosyo-mekânsal formlar halinde yeniden biçimleniyor. $\mathrm{Bu}$ süreçte sınırlar, kapalı sitelerde kontrollü girişler ve duvarlar gibi fiziksel özellikleri ile ön plana çıkarken, getto ve çöküntü alanlarında dışarıdan gelenlerin güvenliğini tehdit eden algısal bir boyut kazanıyor (Evren, 2007, 11-21).

Küreselleşme süreci ile ortaya çıkan bir diğer olgu metropollerde güvenlikli sitelerin sayıca artışıdır. İlgili literatürde kapalı cemaatler/topluluklar, güvenlikli siteler,kapalı siteler, kapalı yerleşmeler,müstahkem adacıklar, özel siteler, korunaklı yerleşmeler, refah adacıkları, kapalı adacıklar, kurtarılmış adacıklar gibi değişik adlarla nitelenen bu tür siteler de toplumumuzda sayıca artmaktadır (Alver, 2007, 93). Steril hayatın mekânda somutlaşması olarak değerlendirilen güvenlikli siteler, başka hayatlardan, başka hayat tarzlarından kendini ayıran, uzakta tutan bir anlayışın göstergesidir.

İçli'ye göre, modernleşmeci yaklaşımların tersine kentler ya da yaşanılan mekânlar günümüzde giderek sosyal ve mekânsal ayrımlaşmanın aracı haline gelmiştir. Toplumsal sınıfları giderek birbirine yabancılaştırmakta, eşitlikçi ve bütünleştirici olmaktan çok dışlanmışlık ve yoksulluk ile zenginlik ve gösterişin birlikte arttığı yerler haline dönüşmektedir. İçli, Denizli'de gerçekleştirmiş olduğu Statü Sembolü Olarak Konut ve Konut Kullanımı başlıklı araştırmada konut kullanımını etkileyen mekânsal ve sınıfsal farklılıkları ayrıntılı olarak ele almaktadır (İçli, 2010, 117).

Kentsel mekânla ilgili tartışmalar, kentlerde toplumsal katmanlaşmaya göre değişen bir mekânsal katmanlaşmanın olduğunu göstermektedir. Üst sınıf alanları, orta sınıf alanları ya da işçi sınıfi mahalleleri gibi mahallelerde farklı toplumsal katmanların, yaşama alanlarının niteliklerinin de farklı olduğu kolayca gözlemlenebilmektedir. Günümüzde kentsel mekân hem alt sosyo-ekonomik düzeyde hem üst sosyo-ekonomik düzeyde çeşitlenip ayrışmıştır (Güçlü, 2009, 183-215). Bu durum 1970'lere kadar kabul edilen kente gelen, göç eden bireylerin kentte kalış süresi arttıkça modernleşeceği şeklindeki modernleşmeci bakış açısının da eleştirilmesine yol açmıştır. Artık toplumumuzdaki kentleşme yumuşak-bütünleştirici kentleşmeden gergin-dışlayıcı kentleşmeye geçiş olarak adlandırılmaya başlanmıştır (Işık, \& Pınarcıoğlu, 2002, 127).

$\mathrm{Bu}$ konuda kullanılan kavramlardan biri de "mekânsal yarlma" kavramıdır. "Mekânsal yarılma" kentsel topluluğun bir kısmının taşıdığı dezavantajlar dolayısıyla, (örn. Yoksul olma, işsiz olma, sosyal dışlanmaya muhatap olma, toplumsal kaynaklara erişme noktasında örgütsüz olma, kadın hane reisi olma, eğitim düzeyi düşük olma, yeterli kamu hizmeti alamama gibi) kentin görece varsıl veya orta düzey statü gruplarından ayrılmalarını, kentsel mekânda kendileriyle benzer konumları olan kümelerle bir araya gelmelerini, çoğu kez kendileri dişında kalan kesimlere kapalı duygu ve davranışlar geliştirmelerini, yoksulluk ve diğer dezavantajlar bakımından oldukça türdeş mekânlarda toplanmış olmaları dolayısıyla, yoksulluktan çıkış için gereken olanaklardan yoksunluğu anlatmaktadır (Bıçk1, 2006, 481).

\section{Sonuc}

Küreselleşme süreci ile birlikte sosyolojide inceleme nesnesi olarak artık toplumu temsil eden ulus devletlerin yerini kentlerin aldığını söylemek abartılı olmayacaktır. Bu anlamda kent pek çok bilim dalının incelediği bir konu olarak kentsel çalışmalar adı altında konumlandırılmaya başlanmıştır. Adı kentsel çalışmalar olsa da kentin sosyolojik analizinin hala önemini koru- 
duğunu görmekteyiz. Mimarlık, coğrafya, tarih, siyaset bilimi, şehir ve bölge planlama, iktisat gibi alanlarda yapılan çalışmalar sosyolojik bakışı zenginleştirmektedir. Hemen hemen tüm dünyada nüfusun büyük çoğunluğu kentlerde yaşamaktadır. Dolayısıyla kentlerdeki değişim ve dönüşümleri saptamak toplumdaki dönüşümleri de anlamak açısından önem kazanmaktadır. Küreselleşme süreci ile yerellikler arası etkileşim önem kazanmaktadır. Sonuç olarak, küreselleşme süreci ile birlikte kentlerde mekânsal ayrışma ve kutuplaşmalar, kentsel yenileme ve dönüşüm, kentsel yeni yoksulluk, tarihî kentler, soylulaştırma, kapalı yerleşmeler (Kurtuluş, 2005), güvenlikli siteler (Alver, 2007; İçli, 2010), kentlerde yaşam kalitesi, kentlerin kimliği gibi konularla kentler ve kent sosyolojisi araştırmaları değişen biçim ve içerikte güncelliğini korumakta, yeni araştırma konuları ile bizlerin ilgisini beklemektedir.

\section{KAYNAKÇA}

Alver, K. (2007). Siteril Hayatlar, Kentte Mekansal Ayrışma ve Güvenlikli Siteler. Ankara: Hece Yayınları.

Azman, A. (2009). Kalkınma/Modernleşme Ekseninde Türkiye'de Kent Çalışmaları: 1960'lı Yıllar. Ertan Eğribel-Ufuk Özcan, Türkiye'de Toplum Bilimlerinin Gelişimi, Cilt II, İstanbul: Kitabevi Yayınları, 114-125.

Bıçk1, D. (2006). Kentsel Yeniden Yapılanma Çerçevesinde Mekansal Yarılma, Kentsel Yoksulluk ve Türkiye. Ed. M. Zencirkıran. Türkiye'nin Toplumsal Yapısl, Nova.

Clark, T. N. (2000). Old and New Paradigms for Urban Research Globalization and the Fiscal Austerity and Urban Innovation Project. Urban Affairs Review, September, 36, 3, 3-45.

Doğan, A. E. (2001). Türkiye Kentlerinde Yirmi Yılın Bilançosu. Praksis, 2, 97-123.

Duru, B., \& Alkan, A., (der.), (2002), 20. Yüzyll Kenti. Ankara: İmge.

Evren, Y. (2007), İstanbul Merkez Bölgede Bütünleşme ve Ayrışma: 15. ISOCARP Genç Profesyonel Plancılar Çalıştayı'nın Düşündürdükleri, Megaron, YTÜ Mimarlkk Fak. E-Dergisi 2, 11-21.

Gilderbloom, J. (1988). Is Urban Sociology Dying? Teaching Sociology 16, October, 443-447.

Güçlü, S. (2009). Kentsel Sosyal Problemler. Ed. Nurşen Adak. Sosyal Problemler Sosyolojisi, (s. 183215). Ankara: Siyasal Kitabevi.

Işık, O., \& Melih, P. (2002). Nöbetleşe Yoksulluk, Sultanbeyli Örneği. İstanbul: İletişim Yayınları.

İçli, G. (2010), Statü Sembolü Olarak Konut ve Konut Kullanımı-Denizli Örneği. Pamukkale Üniversitesi Yayınlar1, no:13.

Kaygalak, S. (2001). Yeni Kentsel Yoksulluk, Göç ve Yoksulluğun Mekansal Yoğunlaşması. Praksis 2, 124-172.

Kurtuluş, H. (2005). İstanbul'da Kapalı Yerleşmeler: Beykoz Konakları Örneği. Yay. Haz. Hatice Kurtuluş. İstanbul'da Kentsel Ayrışma, (s. 161-187). İstanbul: Bağlam Yayınları.

May, T., Beth P., Patrick L. G., Saskia S., \& Mike S., (2005). The Future of Urban Sociology. Sociology 39, 343-370. (İçinde: Tim May ve Beth Perry, Continuities and Change in Urban Sociology; Patrick Le Gales, Interesting Times for Urban Sociology; Saskia Sassen, Cities as Strategic Sites; Mike Savage, Urban Sociology in the Third Generation).

Öktem, B. (2006). Neoliberal Küreselleşmenin Kentlerde İnşası: AKP'nin Küresel Kent Söylemi ve İstanbul'un Kentsel Dönüşüm Projeleri. Planlama 2, 36, 53-65.

Öncü, A., \& Petra W., (2005). Mekan, Kültür, İktidar, Küreselleşen Kentlerde Yeni Kimlikler. İstanbul: İletişim Yayınları.

Özyurt, C. (2007). Yirminci Yüzyıl Sosyolojisinde Kentsel Yaşam. Balıkesir Üniversitesi Sosyal Bilimler Enstitüsü Dergisi, Cilt 10, sayı 18, Aralık, 111-126.

Perry, B., \& Alan H., (2002). The Future of Urban Sociology: Report of Joint Sessions of the British and American Sociological Associations. International Journal of Urban and Regional Research, 26, 4, 844-853.

Sassen, S. (2000). New Frontiers Facing Urban Sociology at the Millenium. British Journal of Sociology, $51,1,143-159$.

Smith, N. (2006), Yeni Küresellik, Yeni Şehircilik: Küresel Kentsel Strateji Olarak Soylulaştırma. Çev.: İlknur Urkun-Bowe, İbrahim Gündoğdu. Planlama, 2, 36, 13-29. 
Şen, B., (2006). Ekonomik Gelişmenin Kültürel Stratejileri: İstanbul Kent Merkezleri ve Tarihi Kentsel Alanların Yeniden Yapılandırılması. Planlama 2, 36, 65-77.

Tatlıdil, E., (1992). Kent Sosyolojisi: Kuram ve Kavramlar. Sosyoloji Dergisi, Ege Üniversitesi Yayını, Say1 3, 25-41.

Türkün, A., \& Kurtuluş, H. (2005). "Giriş”, İstanbul'da Kentsel Ayrışma. Yay. Haz. Hatice Kurtuluş. İstanbul: Bağlam Yayınları.

Uysal, Ü. E. (2006). Soylulaştırma Kuramlarının İstanbul'da Uygulanabilirliği: Cihangir Örneği. Planlama 2, 36, 77-93.

Yıldırım, D., \& Haspolat, E. (2010). Değişen İzmir'i Anlamak. Ankara: Phoenix Yayınevi. 
